\title{
The I and the We: Individuality, Collectivity, \\ and Samoan Artistic Responses \\ to Cultural Change
}

April K Henderson

T

hat the Samoan sense of self is relational, based on socio-spatial relationships within larger collectives, is something of a truism-a statement of such obvious apparent truth that it is taken as a given. Tui Atua Tupua Tamasese Taisi Efi, a former prime minister and current head of state of independent Sāmoa as well as an influential intellectual and essayist, has explained this Samoan relational identity: "I am not an individual; I am an integral part of the cosmos. I share divinity with my ancestors, the land, the seas and the skies. I am not an individual, because I share a 'tofi' (an inheritance) with my family, my village and my nation. I belong to my family and my family belongs to me. I belong to my village and my village belongs to me. I belong to my nation and my nation belongs to me. This is the essence of my sense of belonging" (Tui Atua 2003, 5 I).

Elaborations of this relational self are consistent across the different political and geographical entities that Samoans currently inhabit. Participants in an Aotearoa/New Zealand-based project gathering Samoan perspectives on mental health similarly described "the Samoan self . . . as having meaning only in relationship with other people, not as an individual. This self could not be separated from the 'va' or relational space that occurs between an individual and parents, siblings, grandparents, aunts, uncles and other extended family and community members" (Tamasese and others 2005, 303). Drawing on fieldwork in American Sāmoa, United States-based anthropologist Jeannette Mageo has likewise argued that Samoan culture is decidedly more "sociocentric" than "egocentric"; the prevailing "moral discourse" about proper behavior, the "ontological premise" of how Samoans should be, favors those who seem to be dutifully fulfilling the role assigned or expected of them in a hierarchical soci-

The Contemporary Pacific, Volume 28, Number 2, 316-345

(C) 2016 by University of Hawai' $i$ Press 
ety. This entails subverting "inner thoughts or feelings" of the self (loto) to the wishes and expectations of the wider collective, typically an extended family unit, church congregation, or village (Mageo I998). Leo Tanoi, a New Zealand-born Samoan working in the arts sector in Australia for the past two decades, described the weight of responsibility this places on an individual: "Samoan culture is ... strict in a sense that you're very limited. You're the 'we', you're not an individual" (quoted in Drago I998).

That such characterizations of "being" Samoan are important for understanding Samoan culture and continue to act as powerful tenets for guiding behavior within communities is beyond doubt. Caution is necessary, though, when assertions are made about "how people are" that tend toward ahistoricism and the sort of timeless ethnographic present quality for which the discipline of anthropology has long been critiqued. Contemplating future "ways of being" for Samoan people across their broadly dispersed but interrelated networks suggests that these will be informed by shifting values, attachments, and desires and by the influences of the various sites of Samoan settlement. Samoans are, arguably, the most diasporic of Pacific peoples. There is not one Sāmoa, in the sense that the Samoan archipelago has been divided for over one hundred years between two political entities- the US territory of American Sāmoa in the east and the independent nation of Sāmoa to the west. In addition to the real and perceived differences between these two are the various articulations of Samoanness that spring from multiple generations of diasporic residency in the United States, Aotearoa/New Zealand, Australia, and elsewhere. What things do Samoans across all these sites value now? What concrete decisions are being made as a reflection of these values? To what, and where, are Samoans attached? What do they desire? And what effects are shifting attachments having on Samoan senses of self and on whether, when, why, and how one submits one's personal thoughts and beliefs to the will of the collective?

This article reflects on these questions by, first, tracing broad patterns and recent developments that indicate the interplay of global forces and local expressions of Samoanness. It then returns to questions of how, given this context of cultural change, Samoans might be negotiating between individuality and collectivity, "being for the self" and "being for the group." It does so specifically through an exploration of the work of Samoan literary and performing artists, focusing on Sia Figiel's debut novel Where We Once Belonged (1996) and the articulations of diasporic Samoan hip hop lyricists as well as, to a lesser extent, dancers and graf- 
fiti writers. The rationale for focusing on Samoan art and artists is twofold. First, as Edward Said has explicated, an intellectual is an "individual endowed with a faculty for representing, embodying, articulating a message, a view, an attitude, philosophy or opinion to, as well as for, a public" (I994, I I). As consummate public intellectuals, artists are obvious candidates for examining enduring and emerging Samoan responses to relationality, for art has a special capacity to represent our everyday experiences in ways that provoke us to see them anew. Second, and further underscoring the previous assertion, Pacific critical writing evidences a long history of paying attention to the work of art and artists, according to them not just the ability to represent Pacific societies but also the power to shape, change, and build them (Wendt I976, I978, I987; Hau'ofa 2008). It is in the spirit of such writing that this essay understands Samoan literary and performing artists as providing important commentary toward fashioning an Oceanic community of critique capable of navigating future ways of being Samoan.

\section{Fa‘a Sāmoa and Cultural Change}

Anthropological discussions of globalization in the Pacific detail how increased global flows, interconnections, and interdependences prompt complex negotiations over culture and identity (see, eg, Besnier 20I0; Lockwood 2004). More generally, the anthropology of globalization notes how debates over what constitutes an "authentic" cultural self intensify as the "tools for self-making" diversify (Appadurai I996, 3). Discourses of authenticity are certainly evident in Samoan culture; such discourses have only increased as Samoans have dispersed transnationally and settled in new locations (Macpherson I999). In Samoan communities, a desire to delineate cultural insiders and outsiders (say, "real" Samoans from "plastic" or "fiapalagi" [wannabe-white] Samoans) might persist even while the subsets of attributes that are "mobilized to articulate the boundary of difference" shift (Appadurai I996, I5). For example, some of the categories of difference being mobilized may be shifting due to the inevitable demographic changes wrought by decades of significant out-migration. It is difficult to predict whether distinctions made between island-born Samoans and those born overseas will have more or less salience in the coming years, given that the majority of the global population of Samoans now live outside the archipelago. ${ }^{1}$ Similarly, while Samoan language ability remains a critically important arbiter of authenticity for those who 
are themselves fluent (Hunkin-Tuiletufuga 2000), can this continue to be the case for numerous diaspora-raised Samoans-and even some raised in Apia or Pago Pago-who may no longer speak Samoan? There are indications that those with minimal Samoan language competence may believe they can still be "Iо०\% Samoan" regardless of language ability (Wilson 20I0).

One category of difference that has remained of relatively constant importance is the upholding of $\mathrm{fa}^{\prime} a$ Sàmoa, the term widely employed to characterize "the Samoan way." Yet what practicing fa'a Sāmoa actually entails continues to be reworked. An example is families' obligatory responses to fa'alavelave, or the "family emergencies" such as weddings, funerals, or chiefly title bestowals for which Samoan culture is well known. In Sāmoa, such occasions have always marshaled the mobilization of family resources, including expected exchanges of ritualized categories of women's and men's wealth, but there is now an inflation in gift giving, a sort of Samoan keeping-up-with-the-Joneses (Tui Atua 1995; Tuimaleali' ifano 2006). While senses of obligation remain a constant component of fa'a Sāmoa, what is expected in order to fulfill those obligations continues to change significantly and in ways that move Sāmoa further away from a subsistence-based economy to one reliant on imported goods and monetary exchange (Macpherson and Macpherson 2009b).

The forces promoting changes to the economic basis of Samoan society are certainly wider, however, than the face-saving compulsion to contribute to ever-increasing gift-exchange obligations. A powerful array of neoliberal economic ideologies continue to be promulgated throughout the Pacific in the name of development (Firth 2000, 2007). As Claire Slatter emphasized, "The aggressive marketing of neo-liberalism and its core values of individual advancement, private wealth accumulation and open access to resources, strikes at the heart of things that have long been enshrined in law, cultural value systems and social practice in the Pacific Islands" (2006, 107). As an example, Slatter paraphrased an Australian report that stresses that rapid growth and development in the Pacific hinges on "the absolute necessity of abandoning communal land ownership in favour of individual property rights" (2006, I05-106).

The independent nation of Sāmoa has, over the past two decades, been something of a darling of external policy advisors, with the ruling Human Rights Protection Party instituting a range of reforms largely in the absence of effective opposition. Contemplating the future effects of these reforms demands an awareness of the complex and co-constitutive relationship 
between culture and the material conditions that shape and are shaped by it. While it is often glossed as "the Samoan way," historian Mālama Meleiseā has argued that the fa'a Sāmoa is, at its core, a political and economic system whose foundation rests on the fa'amatai system of chiefly authority governing the use and inhabitation of land (Meleiseā I987). Meleiseā's structural definition might be modified by more recent work, indicating that the concept of fa'a Sāmoa, like all ideological concepts, is flexible and open to group manipulation (Liliomaiava-Doktor 2004; Mageo I998; Anae 2002). Yet, even if we think of fa'a Sāmoa as a contextually specific articulation-a hooking up of parts that might, hypothetically, be unhooked (Clifford 200I) - each articulation or disarticulation is accompanied by stakes and consequences. In 2008, the Samoan government's Land Titles Registration Act (LTRA) made fundamental changes to the registration and titling of land, with potential implications for the 80 percent of land that is communally controlled by extended family units (Iati 2009, 20I0; Ye 2009). The changes simplify long-term leasing agreements and enable more large-scale developments, such as the Hawai'ibased South Pacific Development Group's us $\$ 450$ million resort planned for customary land in Sāsina, Savai'i (Tavita 2OI2). Iati Iati has cautioned, "if the Act alienates customary land, the repercussions will extend beyond being a land ownership issue" and "will have very significant implications for the traditional Samoan political framework" (2009, I). If the old communal land tenure system lay at the heart of Meleiseā's formulation of fa'a Sāmoa, we might contemplate what articulation of fa'a Sāmoa will flourish with this rearticulation of land as, if not legally alienable in perpetuity, at least alienable in practice over the duration of a sixty-year lease that comes with an additional sixty-year right of renewal.

These reforms to land tenure in independent Sāmoa are due in part to top-down pressures; as noted above, communal land tenure is repeatedly cited by contracted "experts" as one of the key impediments to industrial investment and development. There are also, however, some quite strong pushes for globalization from the bottom up. It is not just outside consultants and potential foreign investors who are clamoring to free up more freehold or long-term leasable land. According to Tagaloatele Peggy Fairbairn-Dunlop, writing before the passage of the 2008 LTRA, "While the customary land tenure systems are still substantially intact and acknowledged, what every Samoan wants today is their own quarter acre of freehold land, unencumbered, free from matai obligations and which 'we know we will be able to pass on to our own children.' This suggests 
a lack of confidence in the support systems which the customary lands provided" (Fairbairn-Dunlop 200I, 34; italics in original).

Fairbairn-Dunlop listed several reasons for why Samoans are increasingly desirous of freehold land, among them the wish to have "resources free from matai interferences"; the need to have something to offer as collateral when negotiating bank loans (customary land, prior to the passage of the LTRA, could not serve this purpose); and a longing to have something secured under a Western legal framework to pass on to children (200I, 43). These desires point to changing perceptions of security: whereas the communal land tenure system once provided for many a sense of social security-as long as you lived and worked on family land, the family and land ensured that your basic needs were met-many people now desire an alternate sense of security offered by private property held in title under Western law. More specifically, these desires signal a critique of the fa'amatai system that exposes fissures in the idealized narrative of Samoan sociocentrism: observing how those positioned to work the system in favor of themselves and their direct descendants often do, Samoans are less willing to trust that their matai will deal equitably with all branches of the extended family.

Another factor is the influence of diasporic populations-people who have lived for extended periods (or indeed their whole lives) in the alternative land-tenure systems of the United States, New Zealand, or Australia and have returned to the "motherland" with aspirations of entrepreneurship or, at the very least, an "unencumbered" lifestyle (Macpherson and Macpherson 2009a). For diasporic returnees, the obligations of the fa'amatai system can seem onerous and the stakes of displeasing family or village chiefs much higher in an environment where chiefs control land use and residency and, in extreme cases, can decree the destruction of property, banishment, or even death (Tuimaleali'ifano 200I; Huffer and So'o 2000).

This discussion of land reform in independent Sāmoa aptly illustrates how something that is fundamental to at least one (structural) definition of fa'a Sāmoa is changing. It is a salient example of how both top-down and bottom-up forces work in concert to foster tensions between senses of individualism and communalism with regard to concepts of private property. Of course, these tensions are not altogether new. As Morgan Tuimaleali'ifano outlined (200I, 3 I7), the establishment of the independent state of Sāmoa in I 962 was predicated on a balance of "two systems of authority." One, “'Aia tatau," or human rights, is "urban and champi- 
ons the right of the individual.” The enshrining of discourses of universal human rights in the Samoan Constitution owes significantly to the Western advisors who assisted with preparing Sāmoa for independence. These rights don't always sit harmoniously with the other system of authority by which Sāmoa is governed in daily practice, which Tuimaleali'ifano called "aganu'u ma agafanua fa'a Samoa," the custom of the villages and the land, which is "rural and is based on the ancient right of family groups of fa'alupega [genealogies]" (200I, 317, italics in original). While not new, then, tensions between senses of individualism and communalism are exacerbated by processes of globalization that intensify global interconnectedness and its attendant influences on ideas, politics, and culture.

\section{A Literary Take on Relationality, FROM THE "SACRED CENTER"}

$$
\begin{aligned}
& \text { "'I' is 'we' . . always." } \\
& \text {-Sia Figiel, Where We Once Belonged }
\end{aligned}
$$

Samoan artists have evocatively referenced cultural change and Samoan relational identity in their work. Novelist Sia Figiel offers a salient literary example of Samoan sociocentricity in Where We Once Belonged, her 1996 debut novel set in independent Sāmoa and centered on the experiences of an adolescent female protagonist, Alofa, and her friends and village community. Midway through the novel, in a short chapter titled "We," Alofa responds quizzically to an essay topic option offered by her American Peace Corps teacher, "What I saw on my way to school." She reflects, "I didn't know then why I didn't choose essay topic three. I knew only that it was hard to witness something-anything-alone. You were always with someone ... 'I' does not exist Miss Cunningham. 'I' is 'we' . . always" (Figiel 1996, I33; ellipses and italics in original). The book's next chapter opens with further poetic elaboration of this declaration:

"I" does not exist.

I am not.

My self belongs not to me because "I" does not exist.

"I" is always "we",

is a part of the 'aiga [extended family],

a part of the Au a teine [girls' group],

a part of the Aufaipese [choir],

a part of the Autalavou [young peoples' organization], 


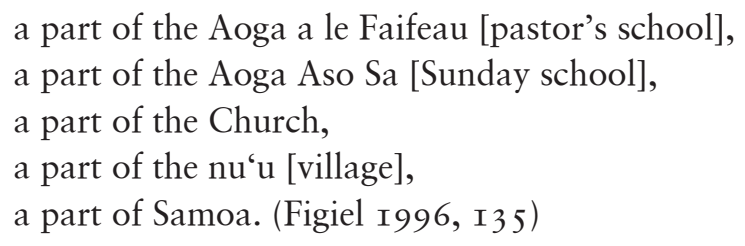

As good literature can, Figiel's novel distills and presents the truism of Samoan relationality in a manner that is more compelling, more evocative, than social science descriptions can muster. In the two decades since the book's publication, I have heard numerous students and colleagues reference this passage from Figiel to describe their sense that Samoan culture and society structurally privilege expressions of collectivity over individualism.

Yet this commonly stated narrative of how Samoan culture functions cannot be taken as an absolute indication of how it actually does function in all contexts and at all times. It's not that Samoans only ever operate according to their sense of responsibility to a larger collective; it is rather that such a mode of operation is what is articulated by Samoan society as the expectation and the ideal. Of course Samoans act on their "inner thoughts" and desires at times, just as peoples in other cultures do-they just may face censure when they do. Thus, the ontological premise of being-for-the-collective is not a transparent reflection of how Samoans always actually are; it is rather the story that Samoans tell themselves (and others) about themselves.

If this complexity of Samoan senses of relationality gets obscured in a too-simple reduction to a strict sociocentric/egocentric dichotomy (these people are like this while those people are like that), the complexity of Figiel's I/we distinction also gets lost if readers only recall the passage cited above and don't take into account her return to the theme at other points in Where We Once Belonged. Indeed, at least two separate analytical essays discussing the novel similarly conclude that Figiel, rather than unquestioningly embracing Samoan articulations of collectivity, critically interrogates the truism of "II' is 'we' . . always" (Keown 2005; Raiskin 2008). Judith Raiskin wrote, "Alofa struggles throughout the novel between two competing but intertwined epistemologies regarding her understanding of herself as an individual" $(2008,27)$. On the one hand, Alofa faces demands from her American Peace Corps teacher to develop an "individualized identity," but "this is an identity that is mystifying, potentially nullifying for a girl who has been raised to measure 
her wealth, prestige, and place in the world through the recitation of her genealogy and current family relations" (Raiskin 2008, 27). On the other hand, "although her Samoan upbringing insists that she is always part of a group, that she know herself and understand her experiences only through that group, the sexual pressure exerted on the girls by the boys and the sexual abuse they receive from men are always experienced alone. Alofa senses an incongruity between what girls are taught in their families ('I' is 'we') and what each girl experiences on her own" (Raiskin 2008, 28). Publishing prior to Raiskin, Michelle Keown similarly observed, "Alofa's sense of alienation from her community galvanizes her" toward the "existentialist individualism" displayed by another character in the novel, Siniva (Keown 2005, 54).

As both Keown and Raiskin pointed out, in subsequent chapters of Where We Once Belonged, the pronoun "I" is repeatedly associated with Siniva, who is portrayed as a social outcast and the "village fool" after returning from her government scholarship experience in New Zealand with uncharacteristically outspoken ideas and criticisms of Christianity and change in Samoan society. Siniva is scorned and ridiculed for expressing herself outside of the parameters sanctioned for her-parameters inextricably linked to the ways Samoan societal hierarchies, and in particular gendered hierarchies, have been informed and inflected by a century and a half of interpretations of Christian ideology. By openly voicing criticisms of society, she creates a rift between herself and the collective. In critiquing Western influences on Samoan "tradition," she is cast as westernized. She becomes an "I" rather than part of the "we."

The final chapter of Where We Once Belonged is in fact titled "I." In it, after Siniva has drowned herself in the sea, protagonist Alofa reflects on the thoughts that Siniva dared to vocalize and that led to her ostracism:

"Now," says Siniva. "Is our turn to re-evaluate, re-define, remember . . if we dare. For this is Darkness. Everyone is living in Darkness and they don't see it."

"Everyone is blinded," said Siniva. "Blinded by too many Bibles. Blinded by too many cathedrals ... too many cars ... too many faleapa [tin houses] ... six million dollar men ... too much bullshit." (Figiel 1996, 233-234; ellipses and italics in original)

And finally, Siniva's apparent suicide note:

Suicide-it is the only way. For isn't that what we're all slowly doing anyway? Each time a child cries for Coca-Cola instead of coconut juice the waves close 
into our lungs. Each time we choose one car, two cars, three cars over canoes and our own feet, the waves close in further. Further and further each time we open supa-keli [tinned spaghetti] . . . pisupo [tinned corned beef] . . elegi [tinned herring] instead of fishing nets . . . raising pigs . . growing taro ... plantations ... taamu [giant taro] . . . breadfruit ... Each time we order fast food we hurry the waves into our lungs. We suffocate ourselves-suffocate our babies and our reefs with each plastic diaper . . formula milk . . . baby powder . . . bottled baby-food and a nuclear bomb, too, once in a while... And agaga [soul; spirit] as we knew it dies in our still biologically functionable bodies, full of junk-food ... darkness food ... white-food ... death food. For that is what we consume on a daily basis. We eat Death and we are eaten by Death, too. Symbiotically we live side by side. (Figiel I996, 234-235; ellipses and italics in original)

While I've often heard the line "'I' is 'we' . . always" popularly quoted as explanation, or even support, of Samoan culture's apparent sociocentrism, critical discussions of the book suggest a more nuanced reading-one that recognizes Figiel's critique of the ways that Samoan understandings of communalism are deployed. In that Siniva is a young, untitled, female individual, her critiques are considered out of place; from the perspective of others, she does not tū i lona tūlaga (stand in her place) or uphold her tofi (responsibilities, heritage, and duties) (Tamasese and others 2005, 303), and she is therefore seen as being at odds with fa'a Sāmoa.

Figiel's work is, of course, literary. Outside the fictional realm, anthropologist Unasa L F Va'a detailed the fate expected to befall the individual who "plays the role of "heretic" in Samoan society: "If such an individual should try to live in a Samoan community, he or she would eventually find himself or herself in all sorts of predicaments, simply because they would not be able to fit into the cultural life of their community." Va'a concluded that attempts to "undermine the system" typically end "unsuccessfully and often tragically" (2006, I I4).

If potential heretics garner castigation and ostracism by appearing to challenge the social order-thus becoming linked to unwelcome changehow do we make sense of moments when their heretical act is to critique other processes of societal change that continue, unabated and with elite sanction? The critiques Siniva raises in Where We Once Belonged precisely point out that Samoan society is already changed through the influence of Christianity and is rapidly embracing more transformations toward a materialistic consumer-driven economy. In Sāmoa, as in many other places in the Pacific, accessing, using, and prominently displaying 
imported goods is a strategy of the elite to assert their position; poor and rural-dwelling island inhabitants may also use this strategy in attempts to close the "prestige gap" between themselves and their typically urbanbased elite counterparts (Macpherson and Macpherson 2009b). Pacific Island nations-especially those such as Sāmoa, where Internet connectivity is comparatively high-are nodes in a global mediascape (Appadurai I996) in which modern global citizenship has been inextricably equated with modes of consumption. There are significant implications for these changing consumption patterns in the Pacific. The increased valuing of mass-produced imported goods in the region and the associated devaluing of locally produced items pose major concerns for public health (Gewertz and Errington 2010), solid waste disposal systems, and import/export balance sheets.

Figiel's character Siniva identifies such changing patterns of consumption as unhealthy for the community in the long term, and she is deemed the village fool for daring to voice such unpopular truths. In her heresy, Siniva aptly personifies the role of the intellectual as outlined by Edward Said: "someone whose place it is publicly to raise embarrassing questions, to confront orthodoxy and dogma (rather than to produce them), to be someone who cannot easily be co-opted by governments or corporations, and whose raison d'etre is to represent all those people and issues that are routinely forgotten or swept under the rug" (I994, I I). Raiskin's analysis of Where We Once Belonged clearly understands Siniva in this Saidian light: "Siniva voices the fury of the intellectual who, educated by the colonial machine, sees beyond the advantages offered her as an administrator of that machine (as a teacher, bureaucrat, professional) and becomes instead a critic of colonialism on behalf of her people, who reject the criticism as madness" (2008, I 5 ).

Perhaps unsurprisingly, it is not uncommon in Pacific Islands literature to feature madmen, madwomen, or village fools as the tellers of unpopular truths. In societies valuing group harmony, these are the characters able to stand apart and behave differently from the collective. Samoan novelist Albert Wendt played with this idea, most notably in his novel Pouliuli (I977); Tongan writer Epeli Hau'ofa employed it to great effect in his satirical novella Tales of the Tikongs (I983; see also Raiskin 2008); and Fijian playwright Larry Thomas covered related territory in his play Men, Women and Insanity (I99I). That Siniva ultimately commits suicide in Where We Once Belonged is testament to the difficulties of being in such a position; that Figiel, Wendt, Hau'ofa, and Thomas continue(d) to 
live and write on after penning their mad, intellectual characters is perhaps a counter-testament to the power of creative production as a space to work through the tensions between individual and communal identities. It is probably not coincidental that Hau'ofa remarked in his autobiographical essay "The Writer as an Outsider" that a three-year period when he'd "assumed the role of social critic, a self-appointed prophet crying in the wilderness, or more correctly a self-righteous public gadfly detested or ignored by the powers that be"-a time when he felt particularly "isolated"-was simultaneously a time of "frantic creativity" that produced multiple books, stories, and poems (Hau'ofa 2008, IOI).

As Where We Once Belonged concludes, Siniva passes a burden of responsibility onto Alofa through the final lines of her suicide note. "'But tell me this once, my little dreamer, did $I$ have a choice? Do you have a choice now that your own eyes are opened to the darkness?" Reflecting on the message, Alofa reaches a moment of seemingly un-Samoan existential resolution: "After reading Siniva's thought, I am silenced. Alone. For the first time I am alone. I am 'I' in its totality-'I' without 'we' . . . without Moa, Lili, girls, boys ... I am" (Figiel I996, 235, 236; italics in original). Confronted with the possibility that there might be truth in Siniva's observations, Alofa ponders whether she too should commit suicide, as so many other people are said to have done in the book and so many Samoan young people do in reality, outside of the world of Figiel's fiction (Macpherson and Macpherson 1987). But Alofa does not choose such a path: "As I thought these thoughts the Tuli of Tomorrow flew high up in the sky, a fue tattooed on her wings, a to'oto'o tattooed on her peak. The Tuli called to me, her voice music to my feet, and I began walking ... walking-walking ... a away from Siniva's grave ... walking now towards Malaefou, towards the new gathering place where 'we' once belonged" (Figiel I996, 236).

How to read such an ending? In walking away from Siniva's grave, back to the village, is Alofa consenting to subvert her newly resolved 'I'-what might be understood as her embracing of her capacity, even responsibility, to voice critique-to the collective status quo? Or is she in fact heading back to her village intent on honoring that responsibility, her spirit buoyed by the appearance of the historically referential tuli bird who, significantly, is gendered female here and bears the symbols of Samoan knowledge and authority, the fue and to'oto'o (orator's flywhisk and staff), tattooed upon her body? Is she intending to employ her individual capacity for critique in the service of articulating a new kind of "we" where all can, again, 
belong? As Keown observed, the novel's "concluding sentence is ambiguous" (2005, 54). Figiel's Where We Once Belonged leaves us pondering the changes that have already occurred in Sāmoa-sā moa, the "sacred center" of the diaspora-and how the next generation will rise to face the challenges they pose.

\title{
A Hip Hop Take on Relationality, from the Diaspora
}

\author{
I represent not me, or the I, but us \\ - MC Flowz, Footsouljahs, \\ "DON'T BREAK THE FlOW"
}

Despite the compelling example provided by Sia Figiel, and by Albert Wendt before her, Samoan novelists are unfortunately still few in number. It is much more common to find a newer generation of Samoan tusitala (storytellers), especially in the diaspora, telling their tales in the form of spoken-word poetry or as rhymes rapped over musical accompaniment. Both forms are more immediate, accessible, social, and more promoted via US-influenced global media than the fairly solitary practice of the longform writer. Both contemporary spoken-word performance poetry and the hip hop culture from which rap music springs share a genealogy of influence from African-American expressive cultures. Critical writing about these expressive cultures evidences its own contextually specific discussions of tensions between collectivity and individuality, with black artists shouldering their own weighty "burden of representation" and expectations of communal responsibility (Mercer I990; see also Gilroy I993; Watkins 2005).

To the casual observer, and to judge by the numerous Samoan invocations of hip hop's “disruptive" effects on communities (see, eg, Henderson 2010, 298-300), Samoan culture and hip hop culture might appear quite divergent. Samoan culture consistently articulates a valuing of the collective, the "we," over the individual, while hip hop art forms proclaim equally vociferous valorization of the "I." Hip hop culture, as its numerous critical interlocutors have asserted, is fundamentally premised on an ethos of competitive individualism-on trumpeting the talents, successes, and superiority of the individual artist self and brazenly detailing the inferiority of potential challengers. As Nelson George vividly summarized, "Hip hop is a world of $I$ opposing $I$ over microphones aimed like Uzis. Be it East Coast versus West Coast, Bronx versus Brooklyn, activists versus gangsters, rappers versus $\mathrm{R} \& \mathrm{~B}$, hip hop exists in a state of 
perpetual combat, constantly seeking sucker MC's to define itself against" (1992, 87; italics in original). If one of the sharpest criticisms in Samoan culture is that a person appears to be fa'amaualuga-wanting to be or acting above their station in life-the hip hop artist unabashedly strives for a position of recognized dominance and prestige. This is most readily apparent in the boastful raps of hip hop lyricists or emcees, but the predilection for competitive self-promotion occurs among deejays, dancers, and graffiti artists as well. Examples from Samoan emcees are legion. At the southern end of the Samoan diaspora, there's Scribe, whose charismatic lyricism and crossover success cemented the mainstreaming of local hip hop in Aotearoa/New Zealand in 2003-2004, emphatically telling listeners, "There's no one like me!" 2 Or there's Scribe's first cousin, emcee and vocalist Ladi6, demonstrating that lyrical boasting is not just a male domain: "“98 'til now, I been holdin' it down / Got no time to play with fools, ain't no fuckin' around" (2010). In Hawai'i, Pou Jackson's "Lyrically I" reaches cinematic proportions of self-glorification: "King Kong ain't got shit on me / You and what army gon' harm me?" (20I3), while northern California's Drew Deezy matter-of-factly tells us he's "the chosen one" (2008). ${ }^{3}$

Writing about US hip hop contexts, Nelson George pondered the potential source of such obsessive individualistic competitiveness as a "black male essence"- "maybe boasting is just in the bones of brothers," he mused (1992, 87, 86) — but it's more useful to discuss such displays of one-upmanship without recourse to reductive racial essentialism. The performative self-aggrandizement of hip hop culture owes both to long legacies of racialized oppression in the United States, with the lyrical boast an attempt to affirm African-American self-worth in the face of dehumanization and belittlement, and to the specific temporal and spatial context in which hip hop developed in New York City in the I970s and I980s-an environment in which young people of many backgrounds struggled to feel consequential amid the ravages of neoliberal economic restructuring. Some of the earliest and most influential examples of self-glorification in graffiti come, it should be remembered, from New York's working-class Greek and Eastern European youth (Castleman I982).

While appearing quite differently positioned when it comes to self-flattery, it is problematic to assume that Samoan culture and hip hop culture are diametrically opposed poles on a grading scale of sociocentricity and egocentricity. As illustrated earlier, Samoan society in practice can differ from sociocentric ideals. In turn, despite the fact that hip hop artists con- 
stantly refer to themselves in the most egocentric of ways in their art or interviews, their legitimacy and credibility often still rests on their ability to represent a collective. Rare is the rapper, b-boy, or b-girl who represents him- or herself alone without also claiming a crew, street, neighborhood, city, region, or nation, and for decades graffiti artists have been visibly professing their group affiliations, there for all those capable of deciphering it to see. Thus, a Samoan emcee such as Flowz from the pioneering Aotearoa/New Zealand group Footsouljahs can simultaneously proclaim his individual lyrical skills-how he "slays" other emcees with his "wordplay"-while still asserting shortly afterward in the same song, "I represent not me, or the I, but us" (Footsouljahs 2004). All those "I's" in rap lyrics aside, when seen in this light, hip hop culture sounds not so dissimilar to Samoan culture: the successes of the individual-albeit trumpeted in more openly bombastic braggadocio-are ultimately put in service of a larger collective.

Further, recalling Tui Atua Tupua Tamasese Taisi Efi's declaration that he "is not an individual" because he shares a "tofi," an inheritance, that binds him to a family, a village, and a nation, there are numerous examples of Samoan artists referencing these same collectivities in their lyrics and in the carefully curated visual imagery of their music videos and branding. See, for example, Scribe's 2003 video for "Dreaming," in which the emcee's lyrical recollections of childhood are paired with evocative montages of dozens of members of his extended family, or the numerous lyrical references to family made in the music of the Carson, California, pioneers, the Boo-Yaa T.R.I.B.E.—a group composed, of course, of biological brothers. ${ }^{4}$ Samoan hip hop artists also reference their Samoan villages of origin, as evident in videos by Aotearoa/New Zealand-based emcees Tha Feelstyle ("Su'amalie," 2004) and Savage ("I Love the Islands," 2008), both shot on location in independent Sāmoa and featuring the emcees posing with signs emblazoned with the names of their natal villages. ${ }^{5}$

Samoan artists certainly also reference nation, both in terms of specific political entities-observe the independent Samoan flag conspicuously waving in New Zealand-based King Kapisi's 1999 video for "Reverse Resistance" - and in connection to a broader, pan-archipelagic and diasporic transnation of Samoans, as amply displayed in the lyrics of Hawai'i-based Shakhouse Finest's album-opening anthem "Samoa Mo Samoa," which shouts out Samoans in both Samoan political entities as well as "Samoa uma e nofo eseese i le lalolagi akoa" (all the Samoans 
living outside [Sāmoa] in the whole world), including everybody "mai Ausikalia, Niu Sila, Amelika, Hawai'i, Kukuila ma Manu'a, 'Upolu ma Savai'i'" (from Australia, New Zealand, America, Hawai'i, [the American Samoan islands of] Tutuila and Manu'a, [the independent Samoan islands of] 'Upolu and Savai'i) (Shakhouse Finest 2013). Sarina Pearson has usefully discussed the ways King Kapisi's videos craft a "diasporic space" that can "envision and express the complexities of contemporary Samoan diasporic identities" (Pearson 2004, 56). The video for emcee Monsta's 20 Io collaboration with vocalist J-Boog, "This Is Love," further embodies these complexities of the diasporic Samoan transnation. ${ }^{7}$ Samoan J-Boog is from California, while Samoan-Mexican Monsta was raised in Long Beach, California, and based for a significant period in Australia; the song was produced by New Zealand's Dawn Raid Entertainment; and the video, shot on location in independent Sāmoa, features New Zealandbased Samoan and Samoan-Niuean actors already familiar to diasporic audiences from their starring roles in the New Zealand film Sione's Wedding (released as Samoan Wedding in the United States). The video also exemplifies the way in which the Samoan islands remain important central nodes where people from across the diaspora gather-a fact evident to anyone eavesdropping on accents at Faleolo or Pago Pago international airports during busy holiday periods.

There is a difference, however, in that Samoan hip hop artists' stated loyalties and declared "shared inheritances" often don't reside exclusively with Samoan collectivities. Hip hop artists are just as likely to claim and reference other types of groupings that reinterpret senses of family, village, and nation according to hip hop sensibilities. References to the "we," the "us," are ubiquitous but reconstituted in the form of other (or additional) assemblages of people: artists may shout out their natal family, but they also frequently reference their chosen family, fashioned through shared participation in hip hop; the "village" is reconfigured in references to the diasporic, and usually multiethnic, metropolitan "hood," town, or city; the "nation" is reimagined to also include the transnation of global hip hop culture. These articulated relationships to collectivities that are not solely or even predominantly Samoan bespeak deeply felt attachments to an additional "community of sentiment" (Appadurai 1996, 8) - the senses of collective community that Samoan hip hop artists develop with many others in hip hop who think and feel and do as they do, who love what they love, and who show them mutual respect. Uptown Swuite raps about "growing up around Northern Mexican cliques" in California (20I2a), 
while fellow northern California Samoan emcee Drew Deezy explained, as he accepted an award for Song of the Year at the 20I3 Fobbnation Awards in San Francisco, why he "always preach[es] about being a Tokouso, for real: I'm a hundred percent uce, but my brothers are Tongan, so that's why I push this Tokouso movement so strong." ${ }^{8}$ As a further example, a number of Aotearoa/New Zealand's prominent Samoan hip hop artists are members of multiethnic chapters of the Universal Zulu Nation (UZN), the largest and oldest fraternal organization associated with hip hop culture, founded in 1973 by DJ Afrika Bambaataa in the South Bronx, New York. As such, they share reciprocal senses of kinship with UZN "brothers and sisters" from around the world, and these relationships translate into material support such as feeding and housing visiting UZN guests. While these examples may be specific to hip hop artists, these artists are certainly not alone in their "extra-cultural" linkages, as high rates of Samoan intermarriage across the diaspora attest. At least one significant feature of Samoan diasporic experience then-and an irrefutable influence on Samoan futures in diasporic locales, and, in turn, on the Samoan islands to which they remain connected-is the affiliative bonds Samoans have built with non-Samoan peers. ${ }^{9}$

Tropes of familial bonds between hip hop participants are common in Pacific hip hop communities and are invoked even in defense of hip hop's validity vis-à-vis Island-informed conceptions of family and culture. An early example from Aotearoa/New Zealand is an exchange recorded between a young Samoan-Māori dancer and her Samoan mother in Mark Scott's 1985 book, StreetAction Aotearoa. In response to her mother's comments that New Zealand contexts promoted "nuclear families" and that "that extended family feeling" was only present in public dance forums "at a superficial level," the daughter, Viasa, passionately interrupts, explaining of her street dance community, "It is like a family-you get to know everybody, it mightn't be a family to you, but there, everybody's like a brother or sister, everybody's welcome ... there is culture in bop" (Scott I985, 34-35). Such articulations of community in Aotearoa hip hop have been explored in work by Kirsten Zemke-White (2002), who understands them as analogous to community formations in early US hip hop contexts. Closer attention to the everyday lived practices of hip hop artists-not just the apparently egocentric lyrics of rap musicboth within the United States and without, often reveals articulations of communal responsibility and commitments to bringing up the next generation. 
There is another way in which hip hop is not the world of agonistic individuals that it appears, on the surface, to be. One fundamental aspect of hip hop culture that remains woefully under-examined is the culture's entrenched and enduring systems of mentorship-the fact that many artists actively seek out and guide those with lesser experience who have demonstrated talent and initiative. "There exists an innate and intuitive mentoring system in hip hop," wrote Sara Tamati, a Christchurch-raised, Wellington-based Samoan woman who dances and writes graffiti under the name SpexOne. "This could possibly come from hip hop not being a written culture, more orally and artistically passed down. From personal observation, people with skill will take the student and show them some foundational techniques in the specific element of interest. The beginner is not always a young person and is usually anyone who has interest in the art form. There is no set time limit on the mentorship, however at his or her discretion the teacher will decide when it might be time for the student to develop on their own" (Tamati 2004, 56). A particularly poignant example of such a mentoring relationship is recorded in the classic I984 New York documentary Style Wars, during which an older teenaged graffiti writer, Dez, and a younger writer, Trap, discuss the relationship they've built through their art form. The diminutive Trap references the guidance he receives, while Dez voices his concern that the younger writer learn the culture's codes properly, that he "follow the outline" literally and metaphorically. The documentary underscores that Dez's remonstrations are motivated by deep affiliative bonds, even love. "He's like a son to me. I look out for him, he looks out for me. I won't let nothin' happen to him, y'know, he won't let nothin' happen to me-if he can help it. I know from his age-he's I4 now, I'm I6-by the time he get my age he'll be like one of the best people out. If he continues to go on in the years, he could be another Picasso" (Dez in Chalfant and Silver I984).

This evocative example from hip hop's New York homeland is echoed in other hip hop communities worldwide. SpexOne's informative description of hip hop mentoring systems draws from years of personal experience as part of Wellington graffiti crew Triple $S$, observing her husband KERBI's mentoring of younger "writers." In another hip hop art form, Samoan emcees from California to Aotearoa reverently recite lyrical genealogies that place them as inheritors of artistic traditions and as beneficiaries of the explicit or implicit mentoring of their hip hop forebears. For example, Uptown Swuite's 20I 2 track "Discography (2 West With Love)" utilizes both direct referencing and more subtle lyrical allusion to recog- 
nize and name a genealogy of California hip hop artists and music that preceded him (20I2b). At the opposite end of the Samoan diaspora, the song "History in the Making," from the debut solo album of Footsouljahs member Flowz (2008), is even more explicitly constructed as a reverential recitation of the emcee's influences. "I reminisce about back in the days," he begins, before providing a litany of artists and events that shaped his entrée into hip hop:

When Rhys B was the first DMC champ / And Upper Hutt Posse said "E Tu!' to their whole camp / The Mau was Feelstyle and Kosmo's first band / Then Noise'n'Effect and Rough Opinion came next / When DJ Raw was number one turntablist on the decks / Gifted and Brown's where King Kaps was found at / That's the first time I seen Dam Native's kaupapa / And Che Fu left Supergroove to do his own numbers / 1993 Orientation in the summer / Just before I emceed live at the Proud Tour / Southside's finest they in the 'o-4 / That's when I realized hip hop's in Aotearoa / Kosmo and DJ Raw, they seen my hunger / So in I994 we birthed the Footsouljahs / My ma says I'm blessed, my flow is chosen / I paid dues the old way, watch and listen with not too much to say / Research my mentors, study their metaphors / Videos my resource, to watch them work the stage / ' Cuz I knew one day, my music would get airplay, regardless of the hearsay. (Flowz 2008)

For those with the communicative and cultural competency to decipher it, this short excerpt deferentially nods to no less than seven hip hop groups and one funk group; six individual hip hop emcees; New Zealand's first recorded hip hop song (Upper Hutt Posse's "E Tu!"); three key live music events (the Disco Mixing Championships, Victoria University of Wellington's annual orientation week concert, and the I994 national Proud Tour); and two urban locations ("Southside" denotes South Auckland, while "०-4" is Wellington's telephone prefix). The song's other lyrics are just as densely referential to the emcee's selfdescribed "mentors." 10

Finally, though, there may be another sense in which hip hop artists' differing degrees of comfort with the pronoun "I" is not such a superficial divergence after all. In Sia Figiel's Where We Once Belonged, the protagonist Alofa only achieves her sense of individual self-hood after significant pain and loss, but hip hop artists have learned to deliver the "I" with ease. Many Samoan hip hop artists are already, in a sense, heretics. Good Samoans attend church; Samoan hip hop artists . . not so much. Good Samoans conscientiously contain their swearing to sympa- 
thetic peer groups, far from the earshot of pastors and parents; hip hop Samoans, by contrast, are all over YouTube declaring, "Stand the fuck up!" (Scribe 2003). If Alofa's sense of self is interpreted as a sense of individual responsibility for critique, as intimated in Siniva's suicide letter, can this mean that hip hop artists-with their already thick-skinned battle armor-are particularly suited for such a task, if they choose to take it up? Indeed, whereas Siniva was driven to suicide by societal censure, hip hop artists feed off challenges; they turn criticism into art. "Ultimately," wrote one commentator on hip hop dance practices, "battling teaches its disciples how to use style to reconcile opposing forces, a skill that may well be at the heart of hip-hop itself" (Schloss 2006, 27). It's a Samoaninflected take on this battling spirit that American Sāmoa-born, California- and Hawai'i-raised emcee The Uce (aka Slo-Mo) invokes in "If I Ever": using hip hop lyricism's metaphorical weaponry to place himself in the legacy of his Samoan intellectual and physical fighting forebears, he lets listeners know he's got the "Mind of Albert Wendt / with David Tua hands" (The Uce 20I4).

Many Samoan hip hop artists describe, in various ways, how their Samoanness inflects their hip hop and how their hip hop informs their understanding of fa'a Sāmoa. For some, this has meant the creation of a new and effective positionality to negotiate their place in the world. Wellington-based graffiti artist and dancer SpexOne, for example, credits hip hop with giving her the "transferable skill" of self-confidence to contend with a range of cultural, familial, and societal expectations. In an interview I conducted with her in Wellington in 2009, SpexOne reflected:

As a Samoan young girl, I was always told that the oldest girl's position in the family is ... to look after the family. You're pretty much the right hand to your mother. ... I always thought I was equal with my brother, although he didn't see me in the same light, and he would always find ways to bring me down, just to remind me that, "Hey, you're beneath me." And my other brother would do pretty much the same thing. And what I've learned through hip hop is, I have this confidence that, yep, okay, that's where I stand as a Samoan female-and I will take that responsibility on-but the confidence that it [has] built is that I am also an individual Samoan, and because I have to walk these two worlds, it's given me confidence to do that. ... I've got this foot in this Samoan world where I have this role as the older daughter and an older sister, [but] I am also in this hip hop world [where] I have learned all this confidence of being an individual, putting myself on the line, and, back in the day, battling, putting 
my [graffiti] pieces out in public arenas where people can critique [them], and having this, like-just letting things run off my back.

Hip hop, as this quote so evocatively illustrates, can help artists navigate the "I" and the "we." Artists such as SpexOne epitomize the "new type of artist" heralded by Albert Wendt in I978: an artist "who is not bound by traditional styles and attitudes and conventions, who explores his [or her] individuality" - yet who still "strive[s] for community involvement even tho' the new artist must, in his [or her] journey, be the supreme individualist" (Wendt I978, I IO, I II).

Hip hop artists have the capacity, even flair, for critique, but does that mean they will provide it? Given that so much imagery promoted by the commercial US rap music industry champions hyper-consumption, is it likely that critique of such materialism will emerge from hip hop? Outside of the United States, just as within it, some artists are lured by fantasies of consumerist "freedom" as the symbolic negation to their own particular histories of racial or class-based struggle. Samoan artists can be found among these, but they are also among those who are articulating alternative visions. Artists such as California's Uptown Swuite, Auckland-based emcee Tha Feelstyle, or Wellington's SpexOne and her globe-trotting emcee/vocalist sister Ladi6 mobilize their own understandings of what "real" hip hop is, grounding their beliefs in a desire to represent with honesty both their local contexts and what they understand as the original context for the development of hip hop.

At the same time, these artists articulate their understandings of what it means to be Samoan. Some, such as Aotearoa/New Zealand's King Kapisi, are openly disapproving of the ways Christianity has been grafted onto Samoan culture. Other artists are less vocally critical of the Church or other institutions within Samoan society, but through their actions and lifestyles, they attempt to also represent with honesty the facets of Samoan culture they feel to be necessary and relevant to the contexts in which they live and to leave off those that aren't. For some, this means practicing and performing the language or contributing the best they can in their respective environments to an extended family unit. For some, like Tha Feelstyle, it means largely rejecting excessive displays of wealth and valorizing instead an alternate persona of the humble "field style" villager-an identity richly informed by understandings of both "real hip hop" and "real Samoan" cultures. ${ }^{11}$ All of these artists make trips to the Samoan islands-trips that are not always easy, particularly if one 
eschews the comforts of the increasingly common resort developments catering to both white and brown visitors. There, they work out their own ways of being Samoan vis-à-vis those they encounter-including the local Samoan hip hop artists they sometimes collaborate with-while the locals do the same, in turn.

\section{"I" Is "We” Always: Critiquing Community, Community of Critique}

Sia Figiel's fiction poignantly illustrates that Samoan society is already changed and changing, is already edging further along a continuum toward materialism and excessive consumption-observations echoed in the critical writing of Samoan intellectuals such as Tui Atua Tupua Tamasese Taisi Efi (Suaalii-Sauni and others 2009; Tui Atua 1995) and in a book-length treatment by longtime sociological researchers Cluny and La'avasa Macpherson (2009b). Global and regional forces articulate with local prerogatives and issues as Samoans seek a sense of security in private property and centuries-old rituals of exchange become monetized. For both Samoan and hip hop cultures, as with other cultures, there are gaps between expressed ideals and lived realities, and it is these gaps that Samoan artists-both in the islands and in diaspora-so powerfully illuminate.

In the present period, the collective traditions of both Samoan and hip hop cultures can be invoked to justify new, unhealthy ways of being, or they can be interpreted as charters for critical, committed, compassionate visions of an alternative future. Samoan culture is heading wherever Samoans are taking it, and Samoan artists are among those providing salient glimpses of where that could be. One such artist painting Pacific pasts, presents, and futures with his words is Sāmoa-born, Wellingtonraised, and now Auckland-based Kas Futialo, aka "Tha Feelstyle," who considers his artistic and ethical responsibilities carefully: "You should never do things that you don't feel right about. If you do then you're only cheating yourself. If you're going to call yourself the Feel Style you really have to live up to that name." For Kas, music has always been a "way of communicating ... some sort of crossroad where our Pasifika parents and kids can have a conversation" (Tauafiafi 2005, 33). To recall Sia Figiel's evocative reference to the Tuli of Tomorrow in Where We Once Belonged, perhaps in such exhilarating times as these it will be the individuals, like Kas, communicating continuity and change over potent mixtures of old 
and new rhythms, who can provide the beat for an Oceanic community of critique.

EARLY VERSIONS OF THIS ARTICLE were presented at the New Zealand School of Music; the Media, Film, and Television seminar series at Auckland University; and the $20 \mathrm{I} 2$ symposium Oceanic Archives and Transnational American Studies at the University of Hong Kong. I thank the organizers and audiences at these forums for the feedback received. I am grateful as well for the generous and insightful suggestions of two anonymous peer reviewers and The Contemporary Pacific editorial team and the inspiration provided by colleagues and students in the Pacific studies and Samoan studies programs of Va'aomanū Pasifika at Victoria University of Wellington.

\section{Notes}

I Recent censuses recorded 193,483 people in independent Sāmoa (2015, http://www.sbs.gov.ws/index.php/population-demography-and-vital-statistics) and 55,5I9 people in American Sāmoa (20IO, http://www.spc.int/prism/ americansamoa/), while the population identifying Samoan as at least one of their ethnicities was I 84,440 in the United States (2010, http://www.census.gov/prod/ cenzoro/briefs/c20Iobr-I2.pdf), I44,I38 in New Zealand (2013, http://www .stats.govt.nz/Census/20I3-census/profile-and-summary-reports/quickstats -culture-identity/pacific-peoples.aspx), and 55,843 in Australia (20II, https:// www.dss.gov.au/sites/default/files/documents/O2_20I4/samoa.pdf).

2 Scribe's 2004 music video "Not Many (remix)," directed by Chris Graham, is available on YouTube (http://www.nzonscreen.com/title/not-many-remix -2004); this and all the other YouTube items in these notes were accessed 6 April 2015 .

3 Jackson's "Lyrically I" is available on YouTube (https://www.youtube.com/ watch?v=bWjfBbfIZN8) as is Deezy's "IBetcha" (https://www.youtube.com/watch ?v=LxiazBqnIZA\&list=RDQMh $5 \mathrm{IeEiUvKC}_{4} \&$ index=I).

4 Scribe's 2003 music video "Dreaming," directed by Chris Graham, is available on YouTube (https://www.youtube.com/watch? $\mathrm{v}=\mathrm{OkgMtg} B \mathrm{BvvQ}$ ).

5 Tha Feelstyle's 2004 music video "Su'umalie/Ain't Mad at You," directed by Chris Graham, is available on YouTube (http://www.nzonscreen.com/title/ suamalie--aint-mad-at-you-2004), as is Savage's 2008 music video "I Love the Islands," also directed by Chris Graham (http://goodlifefilms.co.nz/musicvideos/).

6 King Kapisi's 1999 music video "Reverse Resistance," directed by Sima Urale, 
is available on YouTube (https://www.youtube.com/watch?v=CbrJeqRhKhY). For a related discussion of "flagging" in Melanesian music videos, see Webb and Webb-Gannon 2016.

7 Monsta and J-Boog's 2oro video, "This Is Love," is available on YouTube (https://www.youtube.com/watch?v=SMtjrEPJpa8).

8 Statement from minutes 9:54-I0:04 on the YouTube video from the awards (https://www.youtube.com/watch?v=AmkQXkojZ-I). Tokoua and uso are Tongan and Samoan terms, respectively, for same-sex sibling. In diasporic slang, these terms and their abbreviated forms (toko/tox/dox and uce) recognize brotherhood or sisterhood within Tongan and Samoan communities, while the neologism tokouso deliberately recognizes and articulates kinship between Samoans and Tongans.

9 There are long precolonial and colonial histories of Samoans affiliating with non-Samoans, expanding the prestige of their collectivities by co-opting or seeking alliances with outsiders. It is perhaps substantively different, though, that historical examples often involved elites-for example, the auspicious political marriages of Samoan chiefs and the daughters of Tongan chiefs, or Samoan independence leader O F Nelson's friendship with Māori leader Sir Maui Pomarewhile the examples here are nonelites.

Io For a comparable Māori example, see Te Kupu's “Autahi,” which the emcee explicitly introduces as "Ko toku whakapapa Hip Hop tenei" (my hip hop whakapapa/genealogy) (2000). A 2015 release from Māori emcee Tipene, "Pioneers," not only name-checks older artists but features a number of them-including Upper Hutt Posse member Te Kupu-in the video, directed by Tipene Harmer, available on YouTube (https://www.youtube.comwatch?v=CYKXDyz4v6I).

I I Tha Feelstyle previously used the name "The Field Style Orator," a moniker informed both by his awareness of Samoan oratorical traditions and the discursive distinctions between "field slaves" and "house slaves" circulating in black nationalist-inflected US rap music in the late-I980s and early I990s.

\section{References}

Anae, Melani

2002 Papalagi Redefined: Toward a New Zealand-Born Samoan Identity. In Pacific Diaspora: Island Peoples in the United States and across the Pacific, edited by Paul Spickard, Joanne L Rondilla, and Debbie Hippolite Wright, I50-I68. Honolulu: University of Hawai'i Press.

Appadurai, Arjun

I996 Modernity at Large: Cultural Dimensions of Globalization. Minneapolis: University of Minnesota Press. 
Besnier, Niko

2010 On the Edge of the Global: Modern Anxieties in a Pacific Island Nation. Palo Alto, CA: Stanford University Press.

Castleman, Craig

I982 Getting up: Subway Graffiti in New York. Cambridge, MA: MIT Press.

Chalfant, Henry, and Tony Silver, directors

I984 Style Wars. PBs broadcast documentary film, 70 minutes. Re-released 2004, Public Art Films, Inc.

Clifford, James

200I Indigenous Articulations. The Contemporary Pacific I 3:468-490.

Drago, Carla, director

I998 Island Style. Documentary film, 52 minutes. Sydney: Video Education Australia.

Fairbairn-Dunlop, [Tagaloatele] Peggy

200 I What Samoans Want Today Is "a Quarter Acre Section of Freehold.” In Flowers, Fale, Fanau and Fa'a Polynesia, edited by Richard Bedford, Robyn Longhurst, and Yvonne Underhill-Sem, 34-49. Asia Pacific Migration Research Network Working Paper 8. Wollongong, NSw: Asia Pacific Research Network Secretariat Centre for Asia Pacific Social Transformation Studies, University of Wollongong.

Figiel, Sia

I996 Where We Once Belonged. Auckland: Pasifika Press.

Firth, Stewart

2000 The Pacific Islands and the Globalization Agenda. The Contemporary Pacific I 2:1 78-I92.

2007 Pacific Islands Trade, Labor, and Security in an Era of Globalization. The Contemporary Pacific I9:I I I-I 35 .

Flowz

2008 History In the Making. On In the Heart of the City. Self-released album.

Footsouljahs

2004 Don't Break the Flow. On Puttin' in Work [album]. Wellington: 2Much Records.

George, Nelson

I992 Buppies, B-Boys, Baps and Bohos: Notes on Post-Soul Black Culture. New York: Harper Collins.

Gewertz, Deborah, and Frederick Errington

2010 Cheap Meat: Flap Food Nations in the Pacific Islands. Berkeley: University of California Press. 
Gilroy, Paul

I993 The Black Atlantic: Modernity and Double Consciousness. Cambridge, mA: Harvard University Press.

Hau'ofa, Epeli

I983 Tales of the Tikongs. Auckland: Longman Paul.

2008 The Writer as an Outsider. In We Are the Ocean: Selected Works, 97-I09. Honolulu: University of Hawai'i Press. Originally published in World Englishes 9 (2): 245-253 (I990).

Henderson, April K

2010 Gifted Flows: Making Space for a Brand New Beat. The Contemporary Pacific 22:293-3 I 5.

Huffer, Elise, and Asofou So'o, editors

2000 Governance in Samoa: Pulega i Samoa. Canberra: Asia Pacific Press, The Australian National University; Suva: Institute of Pacific Studies, University of the South Pacific.

Hunkin-Tuiletufuga, Galumalemana

2000 Pasefika Languages and Pasefika Identities: Contemporary and Future Challenges. In Tangata o te Moana Nui: The Evolving Identities of Pacific Peoples in Aotearoa/New Zealand, edited by Cluny Macpherson, Paul Spoonley, and Melani Anae, I96-2I I. Auckland: Dunmore Press.

Iati, Iati

2009 Controversial Land Legislation in Samoa: It's Not Just About the Land. Paper available on the DevNet (Development Network) website: http://www.devnet.org.nz/sites/default/files/IatiIatiLandLaw Samoa.pdf [accessed 23 March 201 5 ]

2010 Reconsidering Land Reform in the Pacific. Research paper. Wellington: Council for International Development.

Keown, Michelle

2005 Postcolonial Pacific Writing: Representations of the Body. New York: Routledge.

Ladi6

201098 Til Now. On The Liberation Of . . [album]. Auckland: Question Music Ltd.

Lilomaiava-Doktor, Sa'iliemanu

2004 Fa'a-Samoa and Population Movement from the Inside Out: The Case of Salelologa, Savai'i. PhD dissertation, Geography, University of Hawai'i at Mānoa.

Lockwood, Victoria, editor

2004 Globalization and Culture Change in the Pacific Islands. Upper Saddle River, NJ: Pearson Prentice Hall. 
Macpherson, Cluny

I999 Will the "Real" Samoans Please Stand Up? Issues in Diasporic Samoan Identity. New Zealand Geographer 55 (2): 50-59.

Macpherson, Cluny, and La'avasa Macpherson

I987 Towards an Explanation of Recent Trends in Suicide in Western Samoa. Man 22 (2 [June]): 305-330.

2009a "It Was Not What I Had Expected": Some Samoan Returnees' Experiences of Samoa. In Return Migration of the Next Generations: 2 Ist-Century Transnational Mobility, edited by Dennis Conway and Robert Potter, I9-40. London: Ashgate.

$2009 \mathrm{~b}$ The Warm Winds of Change: Globalisation in Contemporary Samoa. Auckland: Auckland University Press.

Mageo, Jeannette Marie

I998 Theorizing Self in Samoa: Emotions, Genders, and Sexualities. Ann Arbor: University of Michigan Press.

Meleiseā, Mālama

I987 The Making of Modern Samoa: Traditional Authority and the Colonial Administration in the Modern History of Western Samoa. Suva: University of the South Pacific.

Mercer, Kobena

I990 Black Art and the Burden of Representation. Third Text 4 (Io): $6 \mathrm{I}-78$.

Pearson, Sarina

2004 Pasifik/NZ Frontiers: New Zealand-Samoan Hip Hop, Music Video, and Diasporic Space. Perfect Beat 6 (4): 55-66.

Raiskin, Judith

2008 Telling Tales Out of School: Sia Figiel and Indigenous Knowledge in Pacific Islands Literature. In Gender and Globalization in Asia and the Pacific: Method, Practice, Theory, edited by Kathy E Ferguson and Monique Mironesco, I 5-36. Honolulu: University of Hawai'i Press.

Said, Edward

I994 Representations of the Intellectual: The Reith Lectures. London: Vintage.

Schloss, Joe

2006 The Art of Battling: An Interview with Zulu King Alien Ness. In Total Chaos: The Art and Aesthetics of Hip-Hop, edited by Jeff Chang, 27-32. New York: Basic Civitas Books.

Scott, Mark I985 StreetAction Aotearoa. Auckland: Arohanui Publications.

Scribe

2003 Stand Up. On The Crusader [album]. Auckland: Dirty Records. 
Shakhouse Finest

2013 Samoa Mo Samoa. On Go Samoan [album]. Middlesex, uk: Shakhouse Productions.

Slatter, Claire

2006 Neoliberalism and the Disciplining of Pacific Island States: The Dual Challenges of a Global Economic Creed and Changed Geopolitical Order. In Pacific Futures, edited by Michael Powles, 9 I-I IO. Canberra: Research School of Pacific and Asian Studies, The Australian National University.

Suaalii-Sauni, Tamasa'ilau, I'ugafa Tuagalu, Tofilau Nina Kirifi-Alai, and Naomi Fuamatu, editors

2009 Su'esu'e Manogi: In Search of Fragrance; Tui Atua Tupua Tamasese Ta'isi and the Samoan Indigenous Reference. Apia: The Centre for Samoan Studies, National University of Samoa-Lepapaigalagala.

Tamasese, Kiwi, Carmel Peteru, Charles Waldegrave, and Allister Bush

2005 Ole Taeao Afua, the New Morning: A Qualitative Investigation into Samoan Perspectives on Mental Health and Culturally Appropriate Services. Australian and New Zealand Journal of Psychiatry 39 (4): 300-309.

Tamati, Sara [SpexOne]

2004 A Window to OUR WORLD. In The Next-An Impression of HipHop Expression, by Yadana Saw, Sara Tamati, and Danica Waiti, I 5-74. Wellington: Global Education Centre.

Tauafiafi, Fatu

2005 Pacific Music from the Roots. Tapu (April): 24-26, 3 I-33.

Tavita, Tupuola Terry

20I2 InvestSamoa Hears about New Resort Projects. Samoa News, 22 September. http://samoanews.com/?q=node/8987 [accessed 6 April 20I5]

Te Kupu

2000 Aotahi. On Ko Te Matakahi Kupu [album]. Wellington: Kia Kaha Productions.

The Uce

20I4 If I Ever. On Fast Food N Gangs [album]. Chicago: Uce Muzic.

Thomas, Larry

I99I 3 Plays: Outcasts, Yours Dearly, and Men, Women and Insanity. Suva: University of the South Pacific.

Tui Atua Tupua Tamasese Taisi Efi

I995 Englishing My Samoan: A Collection of Speeches and Letters. Apia: University of the South Pacific.

2003 In Search of Meaning, Nuance and Metaphor in Social Policy. Social Policy Journal of New Zealand 20 (June): 49-63. 
Tuimaleali'ifano, Morgan

200 I Aia Tatau and Afioga Tutasi: 'Aiga versus Tama a 'Aiga: Manipulation of Old and New Practices; An MP for Falelatai and Samatau in Samoa's 200I Elections. The Journal of Pacific History 36 (3): 3I $7-325$.

2006 Matai Titles and Modern Corruption in Samoa: Costs, Expectations, and Consequences for Family and Society. In Globalisation and Governance in the Pacific Islands, edited by Stewart Firth, 363-37I. Canberra: ANU E Press.

Uptown Swuite

20I $2 \mathrm{a}$ Intro. On Beneath the Lights. Self-released album.

20I 2b Discography (2 West With Love). On The Joy of Painting: The Bob Ross EP. Self-released album.

Va'a, Unasa Leulu Felise

2006 The Fa'asamoa. In Sämoa National Human Development Report 2006: Sustainable Livelihoods in a Changing Sāmoa, edited by Asofou So'o, Unasa L F Va'a, and Telesia Lafotanoa, II3-I35. Apia: Institute of Samoan Studies, National University of Samoa.

Watkins, S Craig

2005 Hip Hop Matters: Politics, Pop Culture, and the Struggle for the Soul of a Movement. Boston: Beacon Press.

Webb, Michael, and Camellia Webb-Gannon

2016 Musical Melanesianism: Imagining and Expressing Regional Identity and Solidarity in Popular Song and Video. The Contemporary

Wendt, Albert Pacific 28:59-95.

I976 Towards a New Oceania. Mana I (I): 49-60.

I977 Pouliuli. Auckland: Longman.

I978 The Artist and the Reefs Breaking Open. Mana 3 (I): IO7-I2I.

I987 Novelists and Historians and the Art of Remembering. In Class and Culture in the South Pacific, edited by Antony Hooper, Steve Britton, Ron Crocombe, Judith Huntsman, and Cluny Macpherson, 78-9I. Auckland: Centre for Pacific Studies, University of Auckland; Suva: Institute of Pacific Studies, University of the South Pacific.

Wilson, Salainaoloa Lisa-Maree

2010 Le Tofu Ne`i Vale Tuulima: Perceptions of Samoan Students, Teachers, and Parents on the Place of the Samoan Language in New Zealand Today. Master's thesis, Pacific Studies, Victoria University of Wellington, New Zealand.

Ye, Ruiping

2009 Torrens and Customary Land Tenure: A Case Study of the Land 
Titles Registration Act 2008 of Samoa. Victoria University of Wellington Law Review 40:827-86I.

Zemke-White, Kirsten

2002 Keeping It Real (Indigenous): Hip Hop in Aotearoa as Community, Culture, and Consciousness. In Cultural Studies in Aotearoa New Zealand: Identity, Space and Place, edited by Claudia Bell and Steve Matthewman, 205-228. Oxford: Oxford University Press.

\section{Abstract}

This article discusses articulations of the Samoan "relational self," traces broad patterns and recent developments that indicate an interplay of global forces and local expressions of Samoanness, and reflects on questions regarding how, given contexts of globalization and cultural change, Samoans might be negotiating between individuality and collectivity_ "being for the self" and "being for the group." As a means of addressing these questions, it explores the work of Samoan literary and performing artists, drawing on the novel Where We Once Belonged by Sia Figiel and on a wide range of Samoan hip hop artists based in California, Hawai'i, and Aotearoa/New Zealand. Situating itself within a history of Pacific critical writing that pays attention to the work of art and artists-according to them not just the ability to represent Pacific societies but also the power to shape, change, and build them-this article understands Samoan literary and performing artists as providing important commentary toward fashioning an Oceanic community of critique capable of navigating future ways of being Samoan.

KEYWORDS: Sāmoa, globalization, identity, Samoan artists, Samoan literature, hip hop, Sia Figiel 